\title{
IDENTIFICATION OF A 28,000 DALTON ENDOCHITINASE IN BARLEY ENDOSPERM
}

\author{
by \\ ROBERT LEAH, JØRN DALGAARD MIKKELSEN"', JOHN MUNDY, \\ and \\ IB SVENDSEN ${ }^{2)}$ \\ Department of Biotechnology, Carlsberg Research Laboratory, \\ Gamle Carlsberg Vej 10, DK-2500 Copenhagen Valby \\ 1) Technological Research Laboratories, Biotechnology Section, \\ De Danske Sukkerfabrikker A/S, Langebrogade 1, DK-1001 Copenhagen K \\ 2) Department of Chemistry, Carlsberg Laboratory, \\ Gamle Carlsberg Vej 10, DK-2500 Copenhagen Valby
}

Keywords: Barley, bean, endochitinase, FPLC, amino acid sequencing, sequence homology

One of the four major basic salt-soluble proteins in barley with a molecular weight of 28,000 Dalton was shown to be an endochitinase. A partial amino acid sequence has been determined, and strong homology to an endochitinase from bean (Phaseolus vulgaris) is demonstrated.

\section{INTRODUCTION}

The salt-soluble fraction of barley endosperm comprises about 40 protein components as determined by crossed immunoelectrophoresis (7). Among these, four proteins migrate cathodically under standard immunoelectrophoresis conditions at $\mathrm{pH} 8.6$ and are called "basic proteins" K, N, Q, and C (8). Protein K with a molecular weight of 30,000 Dalton has been shown to be a protein synthesis inhibitor, PSI (2, 6 ). The amino acid sequence of a 10,000 Dalton protein (probably the basic protein $\mathrm{N}$ ) has been deduced from a cDNA sequence (14) and in part, from amino acid sequencing (22). Its close homology with an $\alpha$-amylase inhibitor isolated from ragi (5) was demonstrated, but no biological function as an inhibitor of amylases or proteases has yet been found. Until now, no biological function has been determined for the 60,000 Dalton protein Q. Protein $C$ with a molecular weight of $28 \mathrm{kD}$ has recently been shown to inhibit the growth of various fungi (17). It was concluded that this protein did not function as a translation inhibitor like PSI, which also exhibits antifungal activity. Fungal growth can be inhibited in other ways e.g. by chitinases which attach and destroy cell walls (18). Recently, a full-length cDNA sequence encoding an endochitinase from Phaseolus vulgaris was published (4). The deduced amino acid

Abbreviations: BASI $=$ Barley $\alpha$-amylase/subtilisin inhibitor; $\mathrm{dpm}=$ disintegrations per minute; FPLC $=$ Fast protein liquid chromatography; P-buffer $=50 \mathrm{~mm}$-sodium phosphates, $\mathrm{pH} 6.0 ; \mathrm{PSI}=$ Protein synthesis inhibitor; SDS-PAGE $=$ Sodium dodecyl-sulphate polyacrylamide gel electrophoresis. 
sequence of this bean endochitinase showed strong homology to that of barley protein C, which was being determined. These observations prompted us to test the probable endochitinase activity of the barley protein $C$. The present paper describes the outcome of the experiments.

\section{MATERIALS AND METHODS}

\subsection{Materials}

CM-Sephadex C-50 was obtained from Pharmacia, Uppsala, Sweden. CM-cellulose type CM-52 was obtained from Whatman, Maidstone Kent, U.K. [ ${ }^{3} \mathrm{H}$ ]-Acetic anhydride (296 $\mathrm{GBq} \times \mathrm{mmol}^{-1}$ ) was purchased from Amersham, Buckinghamshire, UK, and chitosan was obtained from Sigma Chemical Company, St. Louis, MO, USA. The reagents used in amino acid sequencing were purchased from Rathburn, UK, or from Applied Biosystems, Cal., USA.

The high lysine Risø mutant 1508 of barley (Hordeum vulgare L.) was used for this study.

\subsection{Methods}

\subsubsection{Purification of $28 \mathrm{kD}$ barley protein (Protein C)}

Mature barley seeds were ground to a flour in an Alpine 100 LU Hammer Mill with a $0.5 \mathrm{~mm}$ screen. The flour was extracted with six weight volumes of $50 \mathrm{~mm}$-sodium phosphates, $\mathrm{pH} 6.0$ (P-buffer) by continuous stirring for $6 \mathrm{~h}$ at $4{ }^{\circ} \mathrm{C}$. The suspension was centrifuged at $6500 \times \mathrm{g}$ for 5 min and the supernatant was brought to $65 \%$ saturation with solid ammonium sulphate, stirred for $30 \mathrm{~min}$ and then allowed to sediment overnight at $4{ }^{\circ} \mathrm{C}$. The precipitate was collected by centrifugation, redissolved in a minimal volume of P-buffer, desalted by dialysis against several changes of the P-buffer until the conductivity was less than twice of that of the dialysis buffer. Two successive chromatographic purification steps were involved in purification of protein $C$. The initial cation exchange chromatographic step was performed on a CMSephadex column $(55 \times 5 \mathrm{~cm})$ equilibrated with P-buffer. As eluant, a linear sodium chloride gradient ( 0 to $0.4 \mathrm{M}$ ) in P-buffer for $24 \mathrm{~h}$ at room

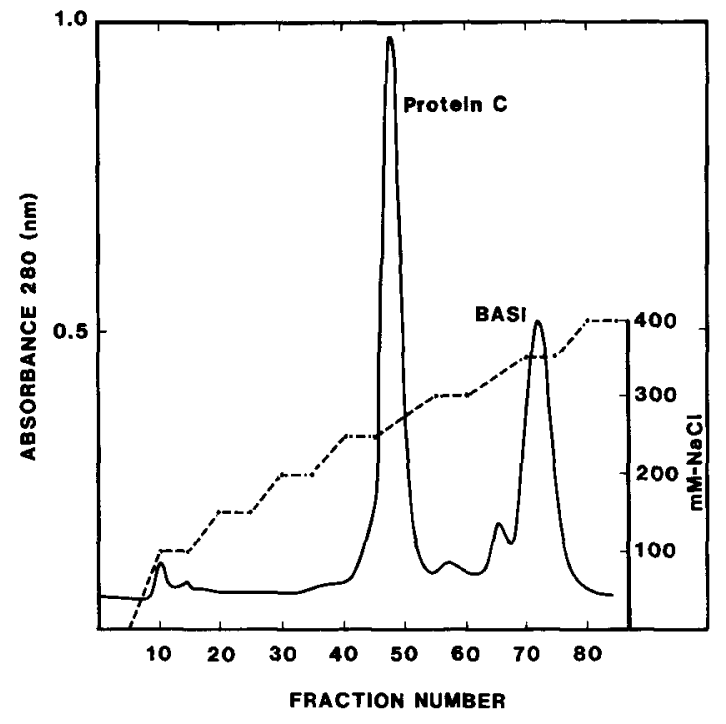

Figure 1. CM-cellulose chromatography of the peak "III" pooled barley protein fraction. About $200 \mathrm{mg}$ of protein dissolved in $20 \mathrm{ml} 20 \mathrm{~mm}$-sodium acetate, $\mathrm{pH}$ $4.75,1 \mathrm{~mm}$-calcium chloride and $1 \mathrm{~mm}-\beta$-mercaptoethanol was loaded onto a $5 \times 25 \mathrm{~cm}$ column of Whatman CM-52 (microgranular) previously equilibrated in the same buffer. Elution with $500 \mathrm{ml}$ start buffer versus $500 \mathrm{ml}$ of the same buffer with 0.4 M-sodium chloride was performed using an adapted gradient former by an LKB 11300 Ultrograd Gradient Mixer as indicated on the figure. The flow rate was 30 $\mathrm{ml} \times \mathrm{h}^{-1}$ and $6 \mathrm{ml}$ fractions were collected. The peaks correspond to the protein C and BASI as indicated.

temperature was employed. The eluates were monitored at $280 \mathrm{~nm}$ and the fractions of interest were collected, desalted by dialysis as above and further purified in a CM-52 cation exchange chromatography column $(5 \times 25 \mathrm{~cm})$ using $20 \mathrm{~mm}$-sodium acetate, $\mathrm{pH} 4.75,1 \mathrm{~mm}$ calcium chloride, $1 \mathrm{~mm}$ - $\beta$-mercaptoethanol (15) as start buffer. Proteins were eluted by a sodium chloride step gradient (indicated in Figure 1) within the starting buffer. The gel materials were pretreated and used in accordance with the manufacturers' instructions. After the final purification step, the eluates of interest were combined and desalted by dialysis prior to lyophilization. 


\subsubsection{Analytical techniques}

Sodium dodecyl-sulphate polyacrylamide gel electrophoresis (SDS-PAGE) was performed according to NeViLLE (16). Fast protein liquid chromatography (FPLC) analyses were performed by using a Pharmacia (Uppsala, Sweden) instrument composed of an LCC-500 liquid chromatography controller, two P-500 high precision pumps, a V-7 sample injector and a UV-1 monitor. The separation was carried out in a prepacked cation exchange column, Mono S HR 5/5.

\subsubsection{Endochitinase assay}

Chitin was synthesized from chitosan by acetylation with ${ }^{3} \mathrm{H}$-labelled acetic anhydride as described by Molano et al. (11). The assay was based on the fact that the reaction product, diacetyl chitobiose, is soluble in water or aqueous trichloroacetic acid, whereas the substrate chitin is insoluble. The incubation mixture consisted of $15 \mu \mathrm{mol}$ potassium phosphate, pH $\left.6.5,5 \mathrm{mg} \mathrm{[}{ }^{3} \mathrm{H}\right]$-chitin $(125,000 \mathrm{dpm} / \mathrm{mg})$ and enzyme to a final volume of $300 \mu \mathrm{l}$. After incubation for $1 \mathrm{~h}$ at $37{ }^{\circ} \mathrm{C}, 300 \mu \mathrm{l}$ of $10 \%$ trichloroacetic acid was added and the suspension was centrifuged for $5 \mathrm{~min}$ at $5,000 \times \mathrm{g}$. 300 $\mu l$ of the supernatant fluid was carefully removed and transferred to a scintillation vial. After addition of $10 \mathrm{ml}$ Ready-Solv HP (Beckmann), the radioactivity was determined by a Beckmann Model 7500 LS liquid scintillation spectrophotometer.

\subsubsection{Amino acid analysis}

Acid hydrolysis of duplicate samples was performed in evacuated and sealed tubes at 110 ${ }^{\circ} \mathrm{C}$ for 24,48 , and $72 \mathrm{~h}$. Cystein was determined separately as cysteic acid after oxidation with performic acid, and tryptophan was determined after acid hydrolysis in methane sulphonic acid (19).

\subsubsection{Amino acid sequencing}

Sequencing was done with a Beckmann Model $890 \mathrm{C}$ as previously described (9) or with a gas phase sequencer from Applied Biosystems,

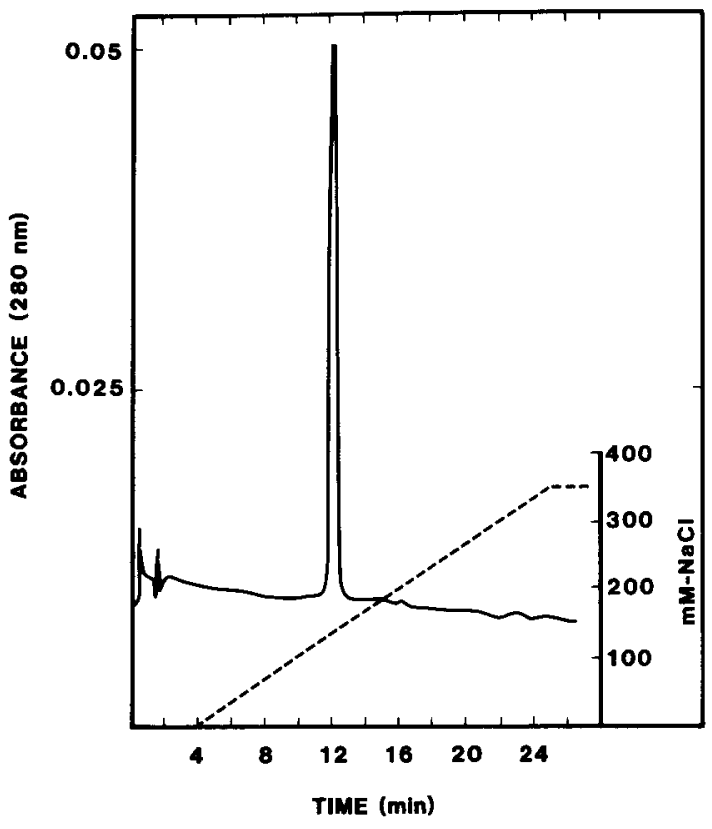

Figure 2. Analysis of purified barley protein $\mathrm{C}$ by FPLC.

The mobile phase A contained 50 mm-sodium acetate, $\mathrm{pH} 5.0$, whereas the mobile phase $\mathrm{B}$ contained A with addition of $1 \mathrm{M}$-sodium chloride. Elution of protein $\mathrm{C}$ was carried out by increasing the concentration of sodium chloride linearily to $0.35 \mathrm{M}$ over the time span indicated on the figure.

Model 470 A, according to the manufacturers' instructions. The PTH-amino acids were identified by HPLC (21).

\section{RESULTS AND DISCUSSION}

\subsection{Isolation of barley protein $\mathbf{C}$}

The initial separation of the salt-soluble proteins of an extract of $1 \mathrm{~kg}$ grain of barley mutant 1508 was performed by cation exchange chromatography at $\mathrm{pH} 6.0$. The elution by a linear sodium chloride gradient exhibited 5 distinct major peaks of proteins (data not shown). Analysis of the protein components of these peaks by SDS-PAGE revealed that in one peak (called III), at least $80 \%$ of the total amount of the protein $\mathrm{C}$ was co-eluted with the barley $\alpha$-amylase/subtilisin inhibitor, BASI (20). This 
"III" fraction, consisting mainly of the two proteins, was further purified by CM-52 cation exchange chromatography as shown in Figure 1. Fractions containing protein $\mathrm{C}$ (fractions 45 to 50 , see Figure 1) were pooled, desalted by dialysis and lyophilized. The degree of purity of the protein was determined by FPLC chromatography as well as by SDS-PAGE. Analysis by FPLC showed a single peak eluted at 170 mM-sodium chloride, $50 \mathrm{~mm}$-sodium acetate, pH 5.0 gradient step (Figure 2). The SDS-PAGE also revealed a single distinct band corresponding to $28 \mathrm{kD}$, verifying that the protein $\mathrm{C}$ had been purified to homogeneity. The yield of the purified protein $\mathrm{C}$ was $82 \mu \mathrm{g} / \mathrm{g}$ grain, which agreed with that previously reported by HEJGAARD et al. (8) and ROBERTS et al. (17).

\subsection{Characterization of protein $\mathbf{C}$}

Protein $\mathrm{C}$ from barley has previously been partially characterized by HEJGAARD et al. (5). It is a basic salt-soluble protein with an isoelectric point of 9.7. Recently it has been shown (13) that protein $C$ is synthesized in the starchy endosperm during the late ( -30 days post anthesis) seed development like the protein synthesis inhibitor, PSI, described by ASANO et al. (2).

ROBERTS et al. (17) observed that a barley seed $28 \mathrm{kD}$ protein and PSI inhibit fungal growth. This $28 \mathrm{kD}$ protein (equal to protein $\mathrm{C}$ ) inhibits growth of Tricoderma reesi very efficiently by addition of as little as $0.1 \mu \mathrm{g}$ of protein to a mycelial invasion-inhibition assay. They suggested (17) that the biological role of the $28 \mathrm{kD}$ protein may be that of an antifungal agent playing an important part in the defence mechanisms of barley seeds against fungal pathogens, but the specific enzymatic activity of the protein has until now been unknown. A candidate would be endochitinase which catalyzes the hydrolysis of the $\beta-1,4$ linkages of N-acetyl-Dglucosamine polymers of chitin, a major component of many fungal cell walls. Higher plants do not contain this substrate for the enzyme, thus suggesting that endochitinase functions as a defence against chitin containing pathogens $(1,3)$.

When we incubated an aliquot of protein $\mathrm{C}$ for $1 \mathrm{~h}$ with ${ }^{3} \mathrm{H}$-labelled chitin polymer, an appreciable amount of radioactivity was released into the soluble fraction (see section 2.2.3). Ten $\mu \mathrm{g}$ of protein $\mathrm{C}$ catalyzed the release of diacetylchitobiose with an average count of $36,000 \mathrm{dpm}$ in three individual experiments (Table I). Comparison of affinity purified endochitinase from $T$. aestivum $(30 \mathrm{kD})$ gave similar result. As a control, the enzymatic activity of the endochitinase from $S$. marcescens is also included in Table I. When protein $C$ initially was heat-inactivated at $90^{\circ} \mathrm{C}$ for $5 \mathrm{~min}$, only 400 dpm was found in the soluble fraction. This result clearly shows that protein $C$ has endochitinase activity.

Table I. Comparison of endochitinase activities of Hordeum vulgare, Triticum aestivum and Serratia marcescens.

\begin{tabular}{|c|c|c|}
\hline Source & Amount of enzyme & $\mathrm{dpm}^{\mathrm{a}}$ \\
\hline Hordeum vulgare (barley) & $10 \mu \mathrm{g}$ & 36,112 \\
\hline Triticum aestivum (wheat) ${ }^{\text {b) }}$ & $10 \mu \mathrm{g}$ & 40,416 \\
\hline Serratia marcescens (eubacteria) ${ }^{c)}$ & 1 unit & 78,811 \\
\hline Hordeum vulgare (barley) & $10 \mu g^{d)}$ & $416^{d)}$ \\
\hline
\end{tabular}

a) $625,000 \mathrm{dpm}$ of ${ }^{3} \mathrm{H}$-labelled chitin was incubated with the specified amount of enzyme for $1 \mathrm{~h}$ at $37^{\circ} \mathrm{C}$ and the released amount of radioactivity was determined as described in section 2.2.3.

b) Pure endochitinase from $T$. aestivum was obtained by affinity column chromatography essentially as described by Molano et al. (12).

c) Endochitinase from S. marcescens was purchased from Sigma (C-1650).

d) As a control, endochitinase from $\mathrm{H}$. vulgare was incubated at $90^{\circ} \mathrm{C}$ for $5 \mathrm{~min}$ before incubation with ${ }^{3} \mathrm{H}$-labelled chitin. 
N-TERMINAL:

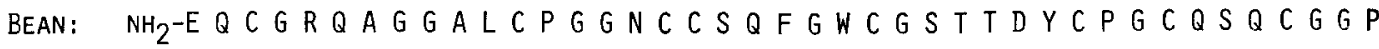

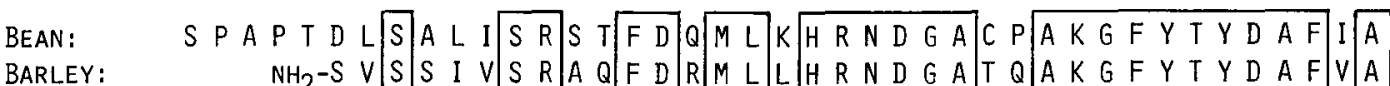

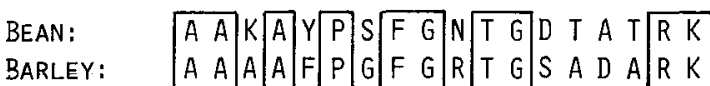

CYANOGEN BROMIDE FRAGMENT:

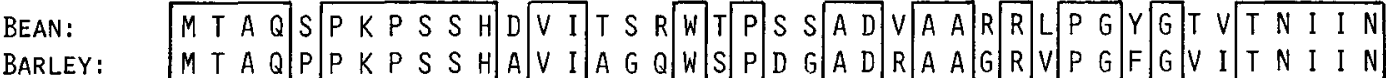

Figure 3. Comparison of the amino acid sequence of bean (Phaseolus vulgaris) endochitinase deduced from a cDNA sequence (4) with two fragments of barley endochitinase. Residues at identical positions are boxed.

That it is a true endochitinase is further demonstrated by the observation that its amino acid sequence is homologous to that of an endochitinase from bean (Phaseolus vulgaris). In Figure 3 is shown the $54 \mathrm{~N}$-terminal amino acids of protein $C$ together with 40 residues of purified peptide obtained by cleavage with cyanogen bromide in $70 \%$ formic acid. The figure also includes the relevant parts of the predicted amino acid sequence of a bean leaf endochitinase derived from a cDNA clone by BROGLIE et al. (4). Identical positioned residues (61 of 104) are boxed in order to visualize the expressed homology between the two proteins. Several smaller peptides derived from cleavage with trypsin show the same degree of homology (not shown). One striking difference between the two proteins is that the bean enzyme extends 46 residues beyond the $\mathrm{N}$-terminal of the barley protein $\mathrm{C}$. Considering the strong homology between the enzymes it appears that these 46 residues are not necessary for catalytic endochitinase activity. On the other hand, it has been proposed by LuCAS et al. (10) that the N-terminal 30 residues of bean endochitinase are involved in the recognition of chitin since this part of the molecule is strongly homologous to wheat germ agglutinin (23), which binds aminoacetylated aminosugars. The rest of the bean endochitinase sequence is completely different from that of wheat germ agglutinin.

The amino acid composition of protein $\mathrm{C}$ is shown in Table II. A comparison was also made with the deduced composition of the bean endochitinase sequence (4) from which the $\mathrm{N}$-terminal 46 residues extension relative to the protein C N-terminal had been subtracted ("BEANFRAGMENT" in Table II). As expected from the sequence homology, there is a reasonably close agreement apart from alanine. Thus, the half-cystine content of both proteins is eight suggesting four disulfide bonds. As seen from the sequence comparison in Figure 3 all of these are not conserved.

Endochitinases have not been demonstrated in barley before, but an endochitinase from wheat germ has been isolated (12). It is a basic protein with a molecular weight of about 30,000 and an amino acid composition close to that of bean endochitinase as shown in Table II. The amino acid sequence of the wheat germ chitinase is not known, but the molecular weight and amino acid composition indicate that this enzyme may be related to the barley and bean enzyme and may contain the extended agglutinin-like $\mathrm{N}$-terminal amino acid sequence which is absent in the barley endochitinase.

\section{ACKNOWLEDGEMENTS}

The skilled technical assistance of Mrs. LONE WIMdRUP, Bodil CORNELIUSSEN, LONE SøRENSEN, and PIA BREDDAM is gratefully acknowledged. 
Table II. Amino acid composition of endochitinases from barley (Protein C), bean and wheat germ.

\begin{tabular}{lcccc}
\hline Amino acid & Barley $^{\text {a) }}$ & Bean-fragment $^{\text {b) }}$ & Bean (4) & Wheat (12) \\
\hline Aspartic acid & 23.4 & 27 & 29 & 28 \\
Threonine & $13.8^{\mathrm{c})}$ & 19 & 22 & 22 \\
Serine & $17.7^{\mathrm{c})}$ & 22 & 26 & 24 \\
Glutamic acid & 18.0 & 16 & 22 & 20 \\
Proline & 17.0 & 15 & 20 & 15 \\
Glycine & 30.7 & 27 & 37 & 52 \\
Alanine & 37.3 & 23 & 26 & 27 \\
Half-cystine & $7.2^{\mathrm{d}}$ & 8 & 16 & 12 \\
Valine & 12.5 & 10 & 10 & 14 \\
Methionine & 1.6 & 2 & 2 & 3 \\
Isoleucine & 10.8 & 11 & 11 & 9 \\
Leucine & 11.3 & 16 & 17 & 13 \\
Tyrosine & 11.9 & 14 & 15 & 14 \\
Phenylalanine & 12.7 & 12 & 13 & 14 \\
Histidine & 4.9 & 3 & 3 & 4 \\
Lysine & 6.9 & 8 & 8 & 8 \\
Arginine & 15.2 & 15 & 16 & 14 \\
Tryptophan & 3.5 & 6 & 7 & 4 \\
\hline No of residues & $259^{\mathrm{e})}$ & 254 & 300 & 297 \\
Molecular weight & $27363^{\mathrm{e})}$ & 27675 & 32205 & 29491 \\
\hline
\end{tabular}

a) This work.

b) Composition of the bean-fragment is based on the amino acid sequence without the $\mathrm{N}$-terminal 46 residues as deduced from (4).

c) Extrapolated values.

d) Determined as cysteic acid.

e) Based on the amino acid numbers derived from nearest integer.

\section{REFERENCES}

1. ABeles, F. B., R. P. Bosshart, L. E. ForRenCE \& W. H. HABIG: Preparation and purification of glucanase and chitinase from bean leaves. Plant Physiol. 47, 129-134 (1970)

2. Asano, K., B. Svensson, I. Svendsen, F. M. POULSEN \& P. ROEPSTORFF: The complete primary structure of protein synthesis inhibitor II from barley seeds. Carlsberg Res. Commun. 51, 129-141 (1986)

3. Boller, T., A. Gehri, T. Mauch \& U. Vögeli: Chitinase in bean leaves: Induction by ethylene, purification, properties, and possible function. Planta 157, 22-31 (1983)

4. Broglie, K. E., J. J. Gaynor \& R. M. Broglie: Ethylene - regulated gene expression: Molecular cloning of the genes encoding an endochitinase from Phaseolus vulgaris. Proc. Natl. Acad. Sci. USA. 83, 6820-6824 (1986)
5. CAmpos, F. A. P. \& M. Richardson: The complete amino acid sequence of $\boldsymbol{\alpha}$-amylase inhibitor $\mathbf{I}-\mathbf{2}$ from seeds of ragi (Indian finger millet, Eleusine coracana Gaertn.). FEBS Lett. 167, 221-225 (1984)

6. COLEMAN. W. H. \& W. K. ROBERTS: Inhibitors of animal cell-free protein synthesis from grains. Biochim. Biophys. Acta 696, 239-244 (1982)

7. GIESE, H. \& J. HeJGAARD: Synthesis of salt-soluble proteins in barley. Pulse-labeling study of grain filling in liquid cultured detached spikes. Planta 161, 172-177 (1984)

8. HejgaARd, J. \& S. E. BıøRN: Four major basic proteins of barley grain. Purification and partial characterization. Physiol. Plant. 64, 301-307 (1985)

9. Johansen, J. T., B. Overballe-Petersen, V. HaseMANN \& I. SVENDSEN: The complete amino acid sequence of copper, zinc superoxide dismutase 
from Saccharomyces cerevisiae. Carlsberg Res. Commun. 44, 201-217 (1979)

10. LuCAS, J., A. HenSChen, F. LOTtSPEICH, U. VoegelI \& T. BOLLER: Amino terminal sequence of ethylene-induced bean leaf chitinase reveals similarities to sugar-binding domains of wheat germ agglutinin. FEBS Lett. 193, 208-210 (1985)

11. Molano, J., A. Duran \& E. Cabib: A rapid and sensitive assay for chitinase using tritiated chitin. Anal. Biochem. 83, 648-656 (1977)

12. Molano, J., I. Polacheck, A. Duran \& E. Cabib: An endochitinase from wheat germ. J. Biol. Chem. 254, 4901-4907 (1979)

13. Mundy, J.. J. Hejgaard, A. Hansen, L. Hallgren, K. G. JøRGENSEN \& L. MUNCK: Differential synthesis in vitro of barley aleurone and starchy endosperm proteins. Plant. Physiol. 81, 630-636 (1986)

14. Mundy, J. \& J. C. Rogers: A probable amylase/ protease inhibitor expressed at high levels in barley aleurone cells: Comparison to the barley amylase subtilisin inhibitor. Planta 169, 51-63 (1986)

15. Mundy, J., I. Svendsen \& J. HejgaArd: Barley $\alpha$-amylase/subtilisin inhibitor. I. Isolation and characterization. Carisberg Res. Commun. 48, $81-90$ (1983)

16. NeVILle JR, D. M: Molecular weight determination of protein-dodecyl sulphate complexes by gel electrophoresis in a discontinuous buffer system. J. Biol. Chem. 246, 6328-6334 (1971)
17. Roberts, W. K. \& C. P. Selitrennikoff: Isolation and partial characterization of two antifungal proteins from barley. Biochim. Biophys. Acta. 880, 161-170 (1986)

18. Schlumbaum, A., F. Mauch, U. Vögeli \& T. BOLLER: Plant chitinases are potent inhibitors of fungal growth. Nature 324, 365-367 (1986)

19. SimpSon, R. J., M. R. NeUberger \& T. Y. LiU: Complete amino acid analysis of proteins from a single hydrolysate. J. Biol. Chem. 251, 1936-1940 (1976) .

20. Svendsen, I., J. HejgaARd \& J. Mundy: Complete amino acid sequence of the $\alpha$-amylase/subtilisin inhibitor from barley. Carlsberg Res. Commun. 51, 43-50 (1986)

21. SVEndSEn, I., B. MARTIN\& I. JonASSEn: Characteristics of Hiproly barley. III. Amino acid sequences of two lysine-rich proteins. Carlsberg Res. Commun. 45, 79-85 (1980)

22. Svensson, B., K. Asano, I. Jonassen, F. M. POULSEN, J. MUNDY \& I. SVENDSEN: A $10 \mathrm{kD}$ barley seed protein homologous with an $\alpha$-amylase inhibitor from Indian finger millet. Carlsberg Res. Commun. 51, 493-500 (1986)

23. Wright, C. S., F. Gavilanes \& D. L. Peterson: Primary structure of wheat germ agglutinin isolectin 2. Peptide order deduces from X-ray structure. Biochemistry 23, 280-287 (1984)

Accepted by E. LuND 